\title{
An Empirical Research on Application of Cohesion Theory in College Listening EFL Teaching
}

\author{
Chunxia $\mathrm{Fu}^{1}$ \\ ${ }^{1}$ Faculty of Foreign Studies, Yangtze University College of Arts and Sciences, Jingzhou, China \\ Correspondence: Chunxia Fu, Faculty of Foreign Studies, Yangtze University College of Arts and Sciences, \\ Jingzhou, China.
}

Received: February 26, 2018 Accepted: March 7, 2018 Online Published: May 14, 2018

doi:10.5539/ells.v8n2p85 URL: https://doi.org/10.5539/ells.v8n2p85

\begin{abstract}
Cohesion Theory of Halliday and Hasan has been widely applied in different subjects of College EFL teaching, particularly in reading comprehension, writing and translation practice. It can also be a practical theory for College Listening EFL Teaching. Based on that theory, an empirical research is carried out among the freshmen from two classes in Yangtze University College of Arts and Sciences, and it lasts for 16 weeks. One of the classes is Control Group (CG) and the other is Experimental Group (EG). Both groups have the same amount of exercises from the same teaching materials but with different guidance in class: the subjects in CG are taught in traditional ways while those in EG are trained with the guidance of Cohesion Theory. After the experimental teaching period, the data collected from students' pre-test and post-test scores is analyzed by the SPSS software program. The pre-test results show that there is no statistically significant difference between the scores of EG and $\mathrm{CG}$ before the experiment $(\mathrm{P}=0.932>0.05)$. While the post-test results demonstrate that there is a considerable improvement on the scores of the subjects in $\mathrm{EG}$ than that of $\mathrm{CG}(\mathrm{P}=0.009<0.05)$.
\end{abstract}

Keywords: Cohesion Theory, college English, EFL teaching

\section{Introduction}

Listening comprehension is one of the most important abilities for college students in English learning. During the real process of college English teaching and learning, the effectiveness of EFL listening teaching is not as good as being expected, or even worse. For many reasons, college students' listening comprehension ability hasn't been improved remarkably, as well as the teachers' teaching methods. Thus it is of great significance to improve the students' listening comprehension ability in EFL teaching.

In order to solve this problem, a new way of improving college English listening teaching is analyzed, which is trying to apply the Cohesion Theory to college English listening teaching. Correspondently, an empirical research is carried out.

\section{Halliday \& Hasan's Cohesion Theory}

The theory foundation of this empirical research is Cohesion Theory of Halliday \& Hasan. Because their book Cohesion in English has been regarded as the the maturity of Cohesion Theory research. It is well known that both of them have contributed a lot to the research on cohesion

In Cohesion in English, Halliday and Hasan define cohesion as "The concept of cohesion is a semantic one; it refers to relations of meaning that exist within the text, and that define it as a text." According to them, cohesion is a semantic relation that makes a passage as both a whole and united one, and it combines all the elements of the passage to get a single new unit. They also make a further division of cohesion into two categories. There are grammatical and lexical cohesion. Grammatical cohesion includes reference, substitution, ellipsis and conjunction. To be specific, reference includes personal, demonstrative and comparative reference, substitution includes nominal, verbal and clausal substitution, ellipsis includes nominal, verbal and clausal ellipsis and conjunction includes additive, adversative, causal and temporal conjunction. Lexical cohesion gets further division into reiteration and collocation.

In listening comprehension, if the listeners can catch the tangible network from the perspective of cohesive approaches, the meaning of the whole text then can be understood much easier. 


\section{Reseach Methodology}

In this part, research questions, research subjects, research methods and research procedures and data analysis techniques are introduced.

\subsection{Research Questions}

The aim of this part is to explore the way to apply Cohesion Theory in College English listening teaching, with the assumption that textual cohesion is playing an very important role in listening comprehension and students' comprehensive listening competence and their awareness of textual cohesion are enhanced as well as their listening comprehension abilities. The research questions are:

1) Is the approach of Cohesion Theory effective in listening teaching?

2) What are the benefits of applying Cohesion Theory in listening?

\subsection{Research Subjects}

As we all know, choosing subjects of the research is very important. The subjects were the students that the author was teaching for the convenience of this research. In order to find the right subjects for the research, a pre-test was taken at the beginning of their second term. The test included the short conversations, long conversations, passages from the teaching material New Horizon College English Listening and Speaking (Book 1) (Zheng Shutang, 2008). As a result of that test, two groups with almost the same English listening abilities and levels were chosen. They were non-English majors in Yangtze University College of Arts and Sciences. All of them were freshmen from two classes, and they are all major in nursing. What's more, there was no big difference in the number of the two groups. There were 25 students in one class and 26 students in the other class. Those 25 students were in EG and 26 students were in CG.

The research subjects were chosen appropriately due to three factors. One factor was that both groups had moderate proficiency of English. Furthermore, they were studying the same major. The last factor was that the numbers of the two groups were without big difference. All of these factors would be essential and helpful for the research results. They would make the research between the two teaching methods comparable and make the results persuasive.

\subsection{Research Methods}

The methods of conducting the questionnaires, completing trial teaching and carrying out tests are involved in this research. The questionnaires are designed to know about the subjects' awareness of cohesion and their attitudes towards listening comprehension. Whether the college students know about Cohesion Theory and how much they know would also be known from the questionnaires.

The empirical teaching was carried out in the second semester of their first academic year. Students had two periods of class per week. During the empirical teaching, two listening tests - the pre-test and the post-test, were carried out. The results of which were used for the empirical data analysis to analyze the efficiency and feasibility of this teaching method. In order to ensure the reliability of empirical teaching, all the research participants were not informed of the research and the empirical teaching. The two groups had the same teacher and used the same materials in class. The teaching materials were those in the book New Horizon College English Listening and Speaking (Book 2) and Teacher's Book (Zheng Shutang, 2008, 2011).

\subsection{Research Procedures}

The empirical teaching was carried out based on Cohesion Theory. At the beginning of the research, a questionnaire about subjects' awareness of cohesion and their attitudes towards listening comprehension was conducted. It would help the teacher get to know whether they are interested in English listening comprehension, whether the college students know about Cohesion Theory and how much they know. Meanwhile, a pre-test was also conducted in the subjects with the purpose to know their listening comprehension levels. In order to make the test results real and effective, the teacher didn't reveal anything about the test, and the students didn't get any preparation before the test. They were just informed that the results of the listening test would be taken into consideration of the final exams, so they took the test seriously. After the pre-test, two groups with the similar English level were chosen as the right subjects for empirical research. One group is the experimental group and the other is control group. The test included the short conversations, long conversations, passages from the teaching materials New Horizon College English Listening and Speaking (Book 1).

Then the empirical teaching was carried out. The systematic introduction of the cohesive devices would be specifically explained to the subjects in EG to make sure they get a general understanding of this theory. Cohesion is one of the necessary conditions for the interpretation of a text and it is essential for getting the 
logical meaning of listening materials. A detailed introduction of Cohesion Theory and its two categories were described. One was grammatical cohesion which includes reference, substitution, ellipsis and conjunction, the other was lexical cohesion which included reiteration and collocation. The specific information about reference, substitution, ellipsis, conjunction, reiteration and collocation were also introduced to the subjects in EG.

During the empirical teaching, the teacher mainly used the approach of cohesive devices in the listening lessons to help the students understand the listening materials through the way of identifying and analyzing the cohesive items and devices in the materials. For CG, the teacher used the traditional way of teaching, beginning a listening class with a brief introduction of some new words and background information which was related to the corresponding listening text. Then the teacher played the audio files, asking learners to listen carefully and finish some exercises. After the students had completed the exercises, the teacher would check the answers. After that, they played the audio files once again to check the answers only to the questions which the students had got wrong answers. This empirical teaching lasted for 16 weeks with two class periods in each week.

After the empirical teaching, a post-test would be conducted in CG and EG. The test materials were chosen from teaching materials and CET 4 (the College English Test Band 4) test papers. Finally, the related data would be collected and analyzed

\subsection{Data Analysis Techniques}

The data collected from the pre-test and post-test is analyzed by the SPSS procedure. Both the Independent Samples T-Test and Paired Samples T-Test are used for data analysis. The Independent Samples T-Test is applied to analyze the test scores of EG and CG in the pre-test in order to see whether there is any statistically significant difference between them. After the empirical teaching, this method is also applied to analyze the test scores of EG and CG in the post-test with the purpose of determining whether there is any statistically significant difference between them. The Paired Samples T-Test is also used for data analysis between the pre-test and post-test scores of each group.

\section{Results and Discussion}

The results of the pre-test and post-test data are stated in the following part. Whether their listening competence has been improved and how much it has been improved will be known from the results.

\subsection{Analysis of Students' Listening Performance in Pre-test}

The analysis of students' listening performance in pre-test is carried out after the analysis of questionnaires is finished. The data collected from the pre-test is analyzed by the SPSS procedure. To be specific, the Independent Samples T-Test is used here to see whether there is any difference between the means of two independent groups.

Table 1. Mean values of EG and CG in the pre-test (total scores: 25)

Group Statistics

\begin{tabular}{llllllll}
\hline & Group & N & Mean & Std. Deviation & Std. Error Mean & $\begin{array}{l}\text { Minimum } \\
\text { Value }\end{array}$ & $\begin{array}{l}\text { Maximum } \\
\text { Value }\end{array}$ \\
\hline \multirow{2}{*}{ Score } & CG & 26 & 11.42 & 3.580 & .702 & 6 & 23 \\
& EG & 25 & 11.52 & 4.408 & .882 & 5 & 20 \\
\hline
\end{tabular}

As showed in Table 1, there is no big difference in the number of the two groups. There are 26 students in CG, and 25 in EG. The purpose of this test was to find the proper research subjects, making sure that these two groups are with the same English listening ability and level before the empirical teaching procedure. As displayed in Table 1, the mean of CG is 11.42, and the mean of EG is 11.52, this shows that the means of the two groups are almost the same. The highest score and lowest score in both groups also have no big difference. However, this result is not enough to prove the significant difference between the two groups. So more results are showed in the following table. 
Table 2. Difference between mean values of EG and CG in the pre-test

Independent Samples Test

\begin{tabular}{|c|c|c|c|c|c|c|c|c|c|c|}
\hline & & $\begin{array}{l}\text { Levene's } \\
\text { Equality } \\
\text { Variances }\end{array}$ & $\begin{array}{r}\text { Test for } \\
\text { of } \\
\end{array}$ & T-test & or Equalit & of Means & & & & \\
\hline & & $\mathrm{F}$ & Sig. & $\mathrm{t}$ & $\mathrm{df}$ & $\begin{array}{l}\text { Sig. } \\
\text { (2-tailed) }\end{array}$ & $\begin{array}{l}\text { Mean } \\
\text { Difference }\end{array}$ & $\begin{array}{l}\text { Std. Error } \\
\text { Difference }\end{array}$ & $\begin{array}{l}95 \% \quad \mathrm{Co} \\
\text { Interval } \\
\text { Difference } \\
\text { Lower }\end{array}$ & $\begin{array}{l}\text { nfidence } \\
\text { of the } \\
\text { Upper }\end{array}$ \\
\hline Score & $\begin{array}{l}\text { Equal variance } \\
\text { assumed } \\
\text { Equal variance } \\
\text { not assumed }\end{array}$ & 2.631 & .111 & $\begin{array}{l}-.086 \\
-.086\end{array}$ & $\begin{array}{l}49 \\
46.241\end{array}$ & $\begin{array}{l}.932 \\
.932\end{array}$ & $\begin{array}{l}-.097 \\
-.097 \\
\end{array}$ & $\begin{array}{l}1.122 \\
1.127\end{array}$ & $\begin{array}{l}-2.352 \\
-2.365\end{array}$ & $\begin{array}{l}2.158 \\
2.171\end{array}$ \\
\hline
\end{tabular}

The results of Independent Samples Test are illustrated in Table 2. The Levene's Test for Equality of Variances shows that $\mathrm{F}$ value is 2.631 and $\mathrm{P}$ value is 0.111 which means that the variances are equal and then the result of 2 -tailed T-test is got. That significance value which means $\mathrm{P}$ value is 0.932 . This figure is more than the required significance level of 0.05 . Therefore, it can be concluded that there is no statistically significant difference between EG and CG before the experiment. The English listening level of CG and EG has no big difference. So these two groups are the right subjects for the author to carry out the research.

\subsection{Analysis of Students' Listening Performance in Post-test}

After the empirical teaching process, the post-test was launched, and the analysis of students' listening performance in post-test is carried out accordingly. The data collected from the post-test is also analyzed by the SPSS procedure. Specifically, the Independent Samples Test is also used here to see whether there is any statistically significant difference between the means of two independent groups after the empirical teaching. The means of both EG and CG in the post-test are illustrated in the following table.

Table 3. Mean values of EG and CG in the post-test (total scores: 25)

Group Statistics

\begin{tabular}{llllllll}
\hline & Group & N & Mean & $\begin{array}{l}\text { Std. } \\
\text { Deviation }\end{array}$ & Std. Error Mean & $\begin{array}{l}\text { Minimum } \\
\text { Value }\end{array}$ & $\begin{array}{l}\text { Maximum } \\
\text { Value }\end{array}$ \\
\hline \multirow{2}{*}{ Score } & CG & 26 & 12.65 & 3.187 & .625 & 8 & 19 \\
& EG & 25 & 15.12 & 3.308 & .662 & 8 & 22 \\
\hline
\end{tabular}

As displayed in Table 3, there is some big difference between the two groups after the teaching process. For one thing, the mean of CG is 12.65 and the mean of EG is 15.12. This shows that the mean of EG is much higher than that of CG after the empirical teaching. To some extent, the improvement of EG in the test scores is more than that of CG. For another, the subject who got the highest score was from EG, while the one who got the highest score was from $\mathrm{CG}$ before the empirical teaching.

However, this result is not enough to prove the significant difference between the two groups. The significance value cannot be known in the above table. So more results should be got and analyzed. The Independent Samples Test is also conducted to analyze the scores of two groups, and the detailed results are showed in the following table. 
Table 4. Difference between mean values of EG and CG in the post-test

Independent Samples Test

\begin{tabular}{|c|c|c|c|c|c|c|c|c|c|c|}
\hline & & \multicolumn{2}{|c|}{$\begin{array}{l}\text { Levene's } \\
\text { Test for } \\
\text { Equality of } \\
\text { Variances }\end{array}$} & \multicolumn{5}{|c|}{ T-test for Equality of Means } & \multirow[b]{2}{*}{$\begin{array}{l}95 \% \\
\text { Interval } \\
\text { Difference } \\
\text { Lower } \\
\end{array}$} & \multirow[b]{2}{*}{$\begin{array}{l}\text { Confidence } \\
\text { of the } \\
e^{\text {Upper }}\end{array}$} \\
\hline & & $\mathrm{F}$ & Sig. & $\mathrm{t}$ & df & $\begin{array}{l}\text { Sig. } \\
\text { (2-tailed) }\end{array}$ & $\begin{array}{l}\text { Mean } \\
\text { Difference }\end{array}$ & $\begin{array}{l}\text { Std. Error } \\
\text { Difference }\end{array}$ & & \\
\hline \multirow[t]{2}{*}{ Score } & $\begin{array}{l}\text { Equal variance } \\
\text { assumed }\end{array}$ & .100 & .753 & -2.712 & 49 & .009 & -2.466 & .909 & -4.294 & -.639 \\
\hline & $\begin{array}{l}\text { Equal variance not } \\
\text { assumed }\end{array}$ & & & -2.710 & 48.709 & .009 & -2.466 & .910 & -4.295 & -.637 \\
\hline
\end{tabular}

In Table 4, the Levene's Test for Equality of Variances shows that $F$ value is 0.100 and $P$ value is 0.753 which means that the variances are equal and then the result of 2-tailed T-test is got. It is showed that the significance value is 0.009 , it is less than the required significance level of 0.05 . Thus, it proves that the difference between two groups is statistically significant. In other words, the subjects in EG outperform those in CG significantly. It proves that the listening competence of subjects in EG has been improved considerably with the guidance of Cohesion Theory.

In general, the results of the post-test demonstrate that the English listening level of EG is higher than that of CG after the empirical teaching process. Since two different teaching methods were applied in these two groups, there is an indication that applying the Cohesion Theory in listening comprehension is more effective than using the traditional teaching method.

\subsection{Comparison of Pre-test and Post-test Results}

Before the empirical teaching, the pre-test results demonstrate that the overall means of two groups are almost the same. The two groups are with almost the same English listening abilities and have the same English competence. However, after the empirical teaching procedure, the post-test results show that there is significant difference between these two groups.

The analysis of the pre-test and post-test results has been made respectively and horizontally in the above parts, the performance of students' listening comprehension in pre-test and post-test is analyzed separately. However, this is not sufficient for a complete research, the performance of students from CG and EG in both the pre-test and post-test also needs to be taken into consideration. Thus, the analysis is made vertically to show the difference of each group between the pre-test and post-test in this part. The Paired Samples T-Test is applied for data analysis. There are two pairs, the pre-test scores and post-test scores of CG are the first pair, and the pre-test scores and post-test scores of EG are the second pair.

Table 5. Mean values of pre-test and post-test scores within CG and EG

Paired Samples Statistics

\begin{tabular}{|c|c|c|c|c|c|c|}
\hline & & & $\mathrm{N}$ & Mean & $\begin{array}{l}\text { Std. } \\
\text { Deviation }\end{array}$ & Std. Error Mean \\
\hline \multirow{2}{*}{ Pair 1} & \multirow{2}{*}{$\mathrm{CG}$} & pre-test & 26 & 11.42 & 3.580 & .702 \\
\hline & & post-test & 26 & 12.65 & 3.187 & .625 \\
\hline \multirow{2}{*}{ Pair 2} & \multirow{2}{*}{ EG } & pre-test & 25 & 11.52 & 4.408 & .882 \\
\hline & & post-test & 25 & 15.12 & 3.308 & .662 \\
\hline
\end{tabular}

The basic information of two pairs is stated in Table 5. The mean of CG in pre-test is 11.42 , and it is 12.65 in the post-test. It indicates that there is certain improvement of English listening competence of students in CG. The mean of EG in pre-test is 11.52, and in the post-test, it is 15.12. It shows that there is significant improvement of English listening competence of students in EG. 
Table 6. Correlation of two pairs within CG and EG

Paired Samples Correlation

\begin{tabular}{lllll}
\hline & & $\mathrm{N}$ & Correlation & Sig. \\
\hline Pair 1 & pre-test scores \& post-test scores in CG & 26 & .332 & .097 \\
Pair 2 & pre-test scores \& post-test scores in EG & 25 & .438 & .028 \\
\hline
\end{tabular}

Table 6 shows that variances of the first pair have the correlation of 0.332 which is close to 1 and the significance value of 0.097 which is higher than 0.05 . It indicates that the correlation is positive and but there is no significant difference between the correlation of pre-test scores and post-test scores in CG. By contrast, the variances of the second pair have the correlation of 0.438 which is also close to 1 and the significance value of 0.028 which is less than 0.05 . It indicates that the correlation is also positive and there is significant difference between the correlation of pre-test scores and post-test scores in EG. The correlation results of the second pair show that the variances of this pair are qualified for T-test. Even though the variances of the first pair are not so proper for T-test, they can still be analyzed by T-test.

Table 7. Comparison of pre-test and post-test mean values within CG and EG

Paired Samples Test

\begin{tabular}{|c|c|c|c|c|c|c|c|c|c|}
\hline & & \multicolumn{8}{|c|}{ Paired Differences } \\
\hline & & \multirow[b]{4}{*}{ Mean } & \multirow{4}{*}{$\begin{array}{l}\text { Std. } \\
\text { Deviation }\end{array}$} & \multirow{4}{*}{$\begin{array}{l}\text { Std. } \\
\text { Error } \\
\text { Mean }\end{array}$} & \multirow{4}{*}{$\begin{array}{l}95 \% \\
\text { Interval } \\
\text { Difference } \\
\text { Lower }\end{array}$} & \multirow{3}{*}{$\begin{array}{l}\text { Confidence } \\
\text { of the }\end{array}$} & \multirow[b]{4}{*}{$\mathrm{t}$} & \multirow[b]{4}{*}{$\mathrm{df}$} & \multirow[b]{4}{*}{ Sig.(2-tailed) } \\
\hline & & & & & & & & & \\
\hline & & & & & & & & & \\
\hline & & & & & & Upper & & & \\
\hline \multirow[t]{3}{*}{ Pair 1} & pre-test scores \& & & & & & & & & \\
\hline & post-test scores & -1.231 & 3.922 & .769 & -2.815 & .353 & -1.600 & 25 & .122 \\
\hline & in $\mathrm{CG}$ & & & & & & & & \\
\hline \multirow[t]{3}{*}{ Pair 2} & pre-test scores \& & & & & & & & & \\
\hline & post-test scores & -3.600 & 4.193 & .839 & -5.331 & -1.869 & -4.293 & 24 & .000 \\
\hline & in EG & & & & & & & & \\
\hline
\end{tabular}

This table shows the value of significance (2-tailed) of the first pair is 0.122 , and the value of significance (2-tailed) of the second pair is 0.000 . The significance value of the first pair is higher than 0.05 , while the second pair's significance value is less than 0.05 . It indicates that the listening competence of subjects in CG hasn't been improved great with the guidance of traditional teaching method. In other words, the traditional method of listening teaching is not very effective. However, the listening competence of subjects in EG has been improved remarkably with the guidance of Cohesion Theory. It indicates that the approach of Cohesion Theory in listening teaching is very effective. With the guidance of this theory, the subjects in EG have made greater progress than those in CG.

Generally speaking, the results of these two tests demonstrate that the English listening level of EG is higher than that of CG after the empirical teaching process. Since two different teaching methods were applied in these two groups, there is an indication that applying the Cohesion Theory in listening comprehension is more effective than using the traditional teaching method. The application of Cohesion Theory in college English listening teaching can improve the students' listening comprehension. Students' comprehensive listening level and their awareness of textual cohesion will be enhanced with the usage of cohesive devices, so will their listening comprehension abilities. What's more, their comprehensive abilities will also be improved.

As for English teachers, it will be an important and practicable teaching method for their English listening teaching. The teachers should firstly have the comprehensive understanding of Cohesion Theory and then develop a keen sense of identifying the cohesion in the listening materials. During the teaching process, they should help the students learn this theory and teach the students to get the right understanding of the materials with the analysis of cohesive devices. What's more, practice makes perfect. More practice in English listening is also very essential, so the students should be encouraged to listen more.

\section{Conclusion}

This research proves the hypotheses that cohesive devices do play important roles in college English listening comprehension. And students' comprehensive listening level and their awareness of textual cohesion are 
enhanced with the application of cohesive devices, so do their listening comprehension abilities. It solves the doubt about the applications of cohesive devices to college English listening comprehension by carrying out the empirical teaching. In this way, more and more teachers will apply the Cohesion Theory in their English listening teaching courses to explore the real effectiveness in classroom teaching. Meanwhile, the implications of this field will be used for other teaching processes, such as reading comprehension, translating or writing of different levels.

For the courses of listening teaching, teachers should first have an entire understanding of the knowledge of Cohesion Theory and the relevant method of teaching. Not only should they know well about textual cohesion but they should also be able to teach the students detailed information on using cohesive devices. While listening, students should make sure that this knowledge can be fundamental to listening comprehension. It should be laid great importance that cohesive devices play an important part in the processing of listening comprehension.

It is unavoidable that there are several limitations of this research. To start with, the study is conducted only in one college, this doesn't involve more colleges and subjects. Meanwhile, the subjects in this study may have some similarities or differences from other universities. Their performance may not be representative for all the college students. The situations of this independent college are not be similar to those of the other colleges. What't more, there may be many factors affecting the performance of the students' listening comprehension. They can't be all considered and analyzed in this research.

In the future research, the number of the research participants from more universities should be increased and more factors affecting the performance of the students' listening comprehension should be considered and analyzed.

\section{References}

Esther, G., \& Fataneh, F. (2012). Developmental Changes in the Nature of Language Proficiency and Reading Fluency Paint a More Complex View of Reading Comprehension in ELL and EL1. Reading and Writing (pp. 1819-1845). https://doi.org/ 10.1007/s11145-011-9333-8

Halliday, M. A. K., \& Hasan, R. (1976). Cohesion in English. London: Longman.

He, L., \& Chen, D. (2017). Developing common listening ability scales for Chinese learners of English. Language Testing in Asia (pp. 1-12). https://doi.org/10.1186/s40468-017-0033-4.

Johnson, K. (2002). An Introduction to Foreign Language Learning and Teaching. Beijing: Foreign Language Teaching and Research Press.

Katya, G. (2016). Teaching and Learning English Grammar: Research Findings and Future Directions. System (pp. 133-135). https://doi.org/ 10.1016/j.system.2016.04.012

Krashen, S. (1981). Second Language Acquisition and Second Language Learning. Oxford: Pergamon Press.

Zheng, S. T. (2008). New Horizon College English Listening and Speaking. Beijing: Foreign Language Teaching and Research Press.

Zheng, S. T. (2011). New Horizon College English Listening and Speaking (Teacher's Book). Beijing: Foreign Language Teaching and Research Press.

\section{Copyrights}

Copyright for this article is retained by the author(s), with first publication rights granted to the journal.

This is an open-access article distributed under the terms and conditions of the Creative Commons Attribution license (http://creativecommons.org/licenses/by/4.0/). 